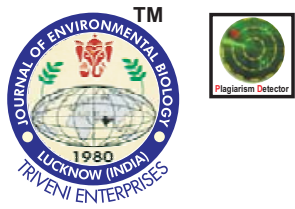

\title{
Herbage yield and bioactive principle of senna as influenced by micronutrient application in soil
}

\section{Authors Info \\ B.B. Basak* and N.A. Gajbhiye ICAR- Directorate of Medicinal and Aromatic Plants Research, Anand-387 310, India \\ ${ }^{*}$ Corresponding Author Email biraj.ssac@gmail.com}

Key words

Cassia angustifolia

Herbage yield

Micronutrients

Sennoside content

\section{Publication Info}

Paper received : 06.10.2016

Revised received : 22.02 .2017

Re-revised received : 24.05 .2017

Accepted: 01.07.2017

\section{Abstract}

Aim : The study was conducted to evaluate the response of micronutrient application on herbage yield and bio active principle of senna for better quality, and thus fetch higher economic return in domestic and international market.

Methodology : A pot culture experiment was conducted during rainy season (July to September) to investigate the effects of micronutrient cations such as $\mathrm{Zn}, \mathrm{Cu}, \mathrm{Fe}$ and manganese $(\mathrm{Mn})$ applications on herbage yield and sennoside content in senna (Cassia angustifolia). Different doses of micronutrient cations were fixed based on the initial availability of these micronutrients in soil. Different yield attributes like the number of flowers and pods and leaves and pods weight per plant was recorded, while sennoside and micronutrient cations content in leaves and pods samples were analysed.

Results : The study revealed that a number of flower and pod as well as total fresh and dry herbage yield (leaf + pod) of senna were improved significantly higher under the micronutrient treatments. Application of $\mathrm{Zn}$, $\mathrm{Cu}, \mathrm{Fe}$ and $\mathrm{Mn}$ recorded higher fresh herbage yield up to 207.4, 202.2, 211.3 and $190.4 \mathrm{~g} \mathrm{plant}^{-1}$ respectively over the control $\left(173.8 \mathrm{~g}\right.$ plant $\left.^{-1}\right)$. Total sennoside yield recorded significantly higher 1.93 and $1.93 \mathrm{~g}$ plant $^{-1}$ under $\mathrm{Zn}$ and $\mathrm{Fe}$ application, respectively, as compared to control (1.26 g plant $\left.^{-1}\right)$. Micronutrient content ( $\mathrm{Zn}$ and $\mathrm{Fe}$ ) in senna leaf and pod significantly increased, while the available micronutrient status in the soil after the harvesting of the crop also improved.

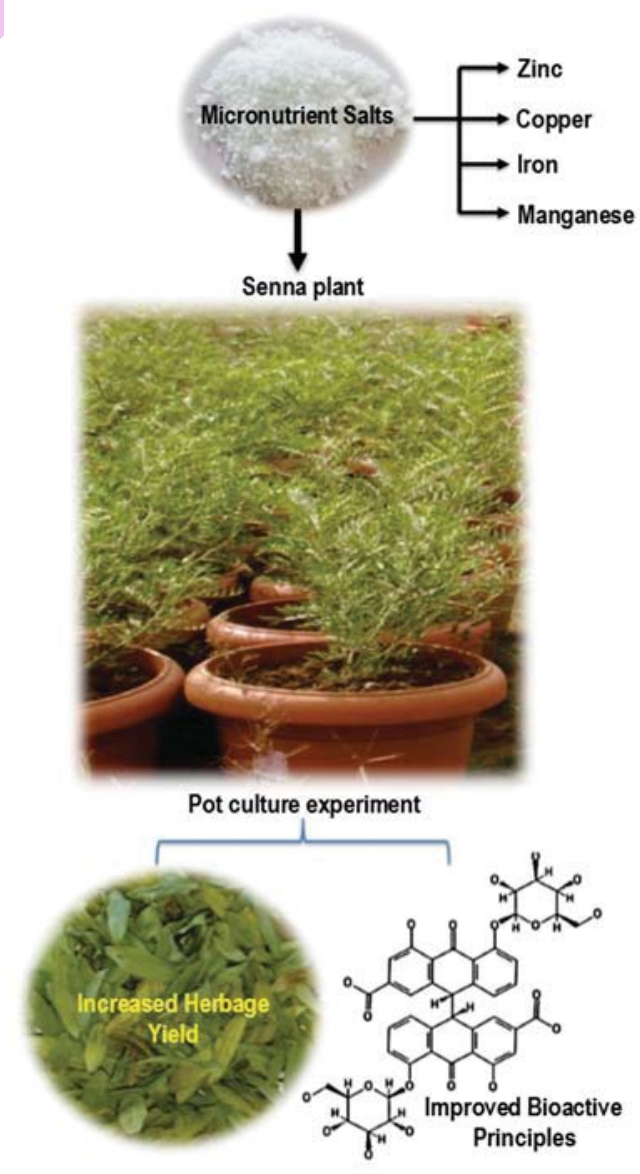

Interpretation : The present study revealed that soil application of micronutrient responded significantly in improving yield and bioactive principle of senna, while increased the micronutrient content in leaf and pod of senna and available micronutrient status in the soil. 


\section{Introduction}

A large number of medicinal plants are used in traditional systems of medicine throughout the world. India is known for its various traditional systems of medicine that have been practiced since ancient times. The World Health Organization (WHO) has estimated that $80 \%$ of the world population in developing countries depends primarily on herbal medicine for basic healthcare (Akerele, 1992). In India, most of the medicinal plants are collected in the wild and some of them are cultivated commercially due to high demand in the national and international market. Senna (Cassia angustifolia) is one of the most important commercially important medicinal plants cultivated in India due to the presence of sennoside in herbage (leaves and pods), which is used as purgative (Bhatia et al., 1980). India is one of the largest producers and exporters of senna leaves, pods and total sennoside concentrate to the world market. Senna (Cassia angustifolia) belongs to the family Caesalpinaceace, is a perennial under-shrub that attains a height of $60-100 \mathrm{~cm}$. It is one of the most important dry land medicinal plants popularly known as Indian senna and Tinnevelly senna. The leaves and pods of this plant are used as laxatives, purgatives and diuretic. The herbage of senna including leaves and pods is also used in decoction powder, confectionery and many other herbal preparations. In European countries, the senna leaf is used for preparing tea. Senna is a valuable medicinal plant in Ayurvedic and modern system of medicine and nearly twenty eight bioactive compounds are isolated from this plant. Among them sennoside $A$ and $B$ are two anthroquinone glycosides present in senna leaves and pods, which are mainly responsible for its purgative action (Patra et al., 2005).

The importance of medicinal plants is considered in terms of their organic constituents, especially secondary metabolite production. So, the trace elements particularly micronutrient cations also have a significant role to play in biological activity either taking part in redox or catalytic reaction or as part of metallo-enzymes. Micronutrients, particularly Zn, $\mathrm{Cu}, \mathrm{Fe}$ and $\mathrm{Mn}$ act either as a metal component of various enzymes or as functional, structural or regulatory cofactors which are associated with synthesis of biomolecules in plants (Marschner, 1995). Unlike macro and secondary nutrients, micronutrients are required by plants in minute quantities, but play a crucial role in the synthesis of secondary metabolites as a part of regulatory enzymes. In this context, micronutrient applications has emerged as an important tool for quantity and quality of agricultural production and to help in overcoming the problems imposed by heredity or environmental stress. Very few studies regarding the response of micronutrients in medicinal plants are reported, which do not reflect the whole picture regarding the effect of micronutrients in medicinal plants. The application of micronutrient cations has significantly influenced the biomass and essential oil yield in some aromatic plants. Foliar application of $3 \mathrm{ppm}$ zinc was found effective in increasing the essential oil yield of Mentha piperita by $28 \%$ (Akhtar et al., 2009). Similarly, Zn application increased the fresh and dry biomass as well as essential oil and menthol concentration in Japanese mint (Misra and Sharma, 1991). A positive effect of $\mathrm{Zn}$ and/or Fe application on basil plant was reported under both normal and saline soil condition (Said-Al Ahl and Mahmoud, 2010). Foliar application of micronutrients has been reported to influence the yield and quality of cultivated medicinal plants like Isabgol and Senna. Foliar application of $\mathrm{Fe}$ and $\mathrm{Zn}$ improved seed yield and mucilage content of Plantago psyllium (Behrouznajhad and ZehtabSalmasi, 2011) whereas soil application of micronutrient cation ( $\mathrm{Zn}, \mathrm{Cu}, \mathrm{Fe}$ and $\mathrm{Mn}$ ) increased seed yield and husk percent in Platago ovate Forsk under greenhouse trial (Basak, 2017). Foliar application of micronutrient solution of $\mathrm{CuSO}_{4}, \mathrm{FeSO}_{4}$ and $\mathrm{ZnSO}_{4}$ on Senna (Cassia angustifolia) significantly influence photosynthetic pigments and organic constituents (Shilpa and Dhumal, 2012). Hence, the application of micronutrients responded well in improving the yield and quality of economic produce of medicinal and aromatic plants. So, management of these micronutrients in medicinal plants may be a promising approach to achieve the desired quantity and quality of produce without altering the natural resource and environment.

So, the present investigation was conducted to study the response of soil application of micronutrients on yield and quality of senna for high economic produce with desired quality so as to meet the domestic and international demand.

\section{Materials and Methods}

Soil sampling and analysis : A bulk soil sample ( $0-15 \mathrm{~cm}$ depth) was collected from the experimental field of ICAR-Directorate of Medicinal and Aromatic Plants Research (DMAPR), Anand, Gujarat for pot culture experiment. For initial characterization, soil samples were collected from the bulk soil used in the pot culture experiment. Soil samples were air-dried and passed through a 2$\mathrm{mm}$ sieve before laboratory analysis. The particle size distribution was analysed by hydrometer method (Bouyoucos, 1962). Soil pH and electrical conductivity were measured in soil: water ratio of 1:2 (Richards, 1954). Soil organic carbon content was estimated by rapid titration method (Walkley and Black, 1934). The soil was analysed for mineral $\mathrm{N}$ (Keeney and Nelson, 1982), available $\mathrm{P}$ (Olsen et al., 1954) and available K (Hanway and Heidel, 1952). Micronutrient cations ( $\mathrm{Zn}, \mathrm{Cu}, \mathrm{Fe}$ and $\mathrm{Mn}$ ) were analysed by extraction of soil $(10 \mathrm{~g})$ by 0.005 (M) DTPA solution (Lindsey and Norvell, 1978) using 1:2 soil: solution ratio. Following this 2 $\mathrm{hr}$ of shaking supernatant solution was collected through filtration. Micronutrient cation content in the solution was measured with an Atomic Absorption Spectrophotometer Model AA 7000. The experimental soil was Fluventic Ustochrept and sandy loam in texture with $69.1,13.8$ and $16.7 \%$ sand, silt and clay. The physico-chemical characteristic of soil were as follows : pH 7.6; EC $0.28 \mathrm{dSm}^{-1}$; SOC 0.29\%; Soil was low fertile having mineral N, $31.7 \mathrm{mg} \mathrm{kg}^{-1}$ available $P$ and $K$ as 6.5 and $82.3 \mathrm{mg} \mathrm{kg}^{-1}$. Available $\mathrm{Zn}, \mathrm{Cu}, \mathrm{Fe}$ and $\mathrm{Mn}$ content in soil was $0.35,0.24,4.42$ and $4.57 \mathrm{mg} \mathrm{kg}^{-1}$, respectively. It was found that the soil was invariably deficient in $\mathrm{Zn}$ and $\mathrm{Cu}$, while marginally deficient in Fe but sufficient in Mn (Tandon, 1999). 
Pot culture experiment : The pot culture experiment was conducted during rainy season (June to September) at the experimental site of DMAPR, Boriavi, Anand. The climate of the study area is semi-arid subtropical region with hot summers and cold winters and a mean annual maximum and minimum temperature of 41.5 and $9^{\circ} \mathrm{C}$, respectively and annual average rainfall of $860 \mathrm{~mm}$ (approximately) occurring mostly during the months of August to September. ALFT-2 cultivar of Indian senna (Cassia angustifolia) was selected for pot culture experiment. Senna is usually cultivated in rain fed dry weather, light well drained soil with $\mathrm{pH} 7.0-8.5$ and responds to application $60 \mathrm{~kg} \mathrm{~N}_{2}$, $40 \mathrm{~kg} \mathrm{P}_{2} \mathrm{O}_{5}$ and $20 \mathrm{~kg} \mathrm{~K}_{2} \mathrm{O} \mathrm{ha}^{-1}$. Five treatments for each micronutrient cation were selected (Table 1) based on the initial micronutrient status of the experimental soil. The required quantity of processed soil $(<5-\mathrm{mm}$ size) was placed on clean polyethylene sheet. Basal dose of FYM (10 t ha') and NPK was added to the soil used for pot filling. Calculated amount of micronutrient fertilizers were added to soil as per treatment and mixed thoroughly. Adequate amount of water was added so as to raise the moisture content of soil to field capacity. Soil treated with respective micronutrient fertilizer (Table 1) was finally placed in polyethylene-lined earthen pots having $45 \mathrm{~cm}$ upper diameter and $40 \mathrm{~cm}$ depth containing $15 \mathrm{~kg}$ soil. Five seeds of senna were sown in each pot. After the emergence of seedlings, they were thinned to a single plant per pot and allowed to grow for the period of 90 days. Weeding and watering were done in regular intervals throughout the experimental period.

Yield parameter analysis : Yield attributes like number of flowers per plant, number of pods per plant, fresh and dry weight of pods were recorded. Pod formation stared at 90 days after sowing (DAS), therefore sampling of pods was done at $120 \mathrm{DAS}$. The fresh weight of leaves was recorded at post flowering stage (120 DAS). For this, five randomly selected healthy plants were uprooted from each treatment and control. Weight of fresh pods and leaves from the plants was measured immediately with electronic top pan balance and expressed in grams per plant and from this average fresh weight of each plant was determined. The fresh leaves and pods samples were kept in an oven at $40^{\circ} \mathrm{C}$ still constant weight were obtained. The constant was recorded as dry weight of leaves and pods. For analysis of sennoside content ten randomly selected third leaf from top of the each plant from control and treatment was selected at $60 \mathrm{DAS}$ and green pods at $120 \mathrm{DAS}$. The samples were kept in an oven at $60 \pm 0.5^{\circ} \mathrm{C}$ for 48 hrs and used for HPLC analysis.

Analysis of sennoside content : The HPLC method was employed for quantitative analysis of total sennosides content as per standard procedure as out lined by Srivastava et al. (1983a). One hundred milligram of dried fine powder was extracted in 20 $\mathrm{ml}$ of $70 \%$ aqueous methanol using a sonication bath for $10 \mathrm{~min}$. Samples and standard solutions were filtered with $0.45 \mu$ membrane filters, while solvents were degassed prior to use. Analysis of sennosides was carried out with HPLC (Shimadzu Corporation, Kyoto, Japan) consisting of two LC-20AD pumps with SPD-20A UV-visible detector at $270 \mathrm{~nm}$ and Grace Alltima
$(100 \times 4.6 \mathrm{~mm}, 3 \mu \mathrm{m})$ analytical column (Crawford Scientific, Scotland, UK) and quantification was done by using reference standards of Sennoside-A (purity 96\%) and sennoside-B (purity 94.5\%) (Sigma-Aldrich, Bangalore, India). The mobile phase consisted of methanol and $1.25 \%$ acetic acid in water, in gradient system, at a flow rate of $1.0 \mathrm{ml} \mathrm{min}{ }^{-1}$ with an injection volume of $10 \mu l$. The total sennoside yield was calculated as follows : [leaf dry weight $x$ sennoside content in leaves] + [pod dry weight $x$ sennoside content in pods] and expressed in milligram per plant (Srivastava etal.,1983b).

Micronutrient cation analysis : Micronutrient content in leaves and pods samples was analysed with an Atomic Absorption Spectrophotometer (AAS: Model AA 7000) through microwave digestion system. Briefly, dried powdered samples $(0.25 \mathrm{~g})$ were weighted in digestion vessel treated with $0.5 \mathrm{ml}$ concentrated nitric acid and then kept overnight, followed by the addition of $5 \mathrm{ml}$ concentrated $\mathrm{HNO}_{3}$. The samples were then placed in a microwave digestion system (Discover-SPD, CEM Corporation, USA) for pre-digestion. After cooling to room temperature, a 250 $\mu \mathrm{l}$ aliquot of $\mathrm{H}_{2} \mathrm{O}_{2}$ was added and samples were subjected to final digestion. Upon completion of second programme, samples were brought to a $25 \mathrm{ml}$ volume with ultra-pure Milli-Q (Millipore) water. Each digested sample was then passed through a $0.45-\mu \mathrm{m}$ filter and the filtrates were collected in separate acid-leached plastic storage bottles. A blank (without analyte sample) applying all other reagents was also prepared under similar conditions.

Statistical analysis : Data generated in triplicate from the pot culture experiment were subjected to analysis of variance (ANOVA) appropriate to the experimental design (Completely Randomize Design). F-test was carried out to test the significance of the treatment difference (LSD at $P=0.05$ ) For the calculation and graphical representation of data, Microsoft Excel (Microsoft Corporation, USA) packages were used.

\section{Results and Discussion}

The influence of micronutrient application on number of flowers and pods per plant of senna was recorded and is presented in Table 2. Results showed that the application of all the micronutrients had significantly increased flower and pod number per plant over the control. The percentage increase ranged from 12.2 to $45.2 \%$ in the case of numbers of flowers per plant, while 21.8 to $45.7 \%$ in the case of the number of pods per plant. The maximum number of flowers per plant (63) was recorded under the treatment containing $5 \mathrm{mg} \mathrm{kg}^{-1} \mathrm{Fe}$, while the next best treatment was $5 \mathrm{mg} \mathrm{kg}^{-1} \mathrm{Zn}$ application (59). However, application of $\mathrm{Cu}$ and $\mathrm{Mn}$ was found comparatively less effective in increasing the number of flowers in senna. Among the different micronutrient treatment combinations, $\mathrm{T}_{4}$ containing $5 \mathrm{mg} \mathrm{kg}^{-1} \mathrm{Zn}, \mathrm{Fe}$ and $\mathrm{Mn}$ and $2.5 \mathrm{mg} \mathrm{kg}^{-1} \mathrm{Cu}$ separately found the best in terms of number of flower per plant. Number of pods per plant also followed the similar trend as found in case of number of flower. The response of $\mathrm{Zn}$ and Fe application was comparatively higher as compared to $\mathrm{Cu}$ and $\mathrm{Mn}$ and overall treatment $\mathrm{T}_{4}$ was found to be most 
effective among all. The number of flowers per plant is one of the important yield contributing character which in also reflected in the number of pods per plant. It has been established that number of flowers and fruits per plant positively correlated to the economic yield of the plant. This increase in the number of flowers and pods might be due to the positive influence of micronutrients on physiological processes of plants. These results are corroborated with the finding of other workers where foliar application of micronutrients improved yield attributes (spike length, seed per spike and spike per plant) in isabgol (Ramroudi, 2011) and chlorophyll content in senna (Shilpa and Dhumal, 2012). Application of bio stimulants (panchakavya, humic acid and moringa leaf extract) which also contains micronutrients was found effective in enhancing number of pods in senna (Balakumbahan and Ragamani, 2010).
The fresh and dry weight of leaves per plant as influenced by different micronutrient treatments are presented in Table 3. The fresh leaf weight per plant was significantly enhanced by the application of different micronutrient treatments over control. The percentage increase in fresh leaf yield under different micronutrients treatments ranged from 19.3 to $47.2 \%$ over control. The highest increase in fresh leaf weight was recorded (185.7 $\mathrm{g} \mathrm{plant}^{-1}$ ) under $5 \mathrm{mg} \mathrm{kg}^{-1} \mathrm{Fe}$ application in soil. The next best treatment $\left(5 \mathrm{mg} \mathrm{kg}^{-1} \mathrm{Zn}\right)$ recorded $181.6 \mathrm{~g}$ fresh leaf per plant. However, treatment containing $\mathrm{Cu}$ and $\mathrm{Mn}$ was comparatively less effective. Dry leaf weight followed almost identical pattern of fresh leaf weight due to micronutrient application. A 19.4 to $46.8 \%$ increase in dry weight was recorded under various micronutrient treatments. The highest dry leaf weight was recorded $(63.3 \mathrm{~g}$ plant ${ }^{-1}$ ) under $5 \mathrm{mg} \mathrm{kg}^{-1} \mathrm{Fe}$ application in soil. It was followed by

Table 1 : Details of micronutrient treatments applied along with source

\begin{tabular}{|c|c|c|c|c|c|c|}
\hline \multirow[t]{2}{*}{ Micronutrient } & \multirow[t]{2}{*}{ Source } & \multicolumn{5}{|c|}{ Treatments (Application rate $\mathrm{mg} \mathrm{kg}^{-1}$ soil) } \\
\hline & & $\mathrm{T} 1$ & $\mathrm{~T} 2$ & T3 & T4 & T5 \\
\hline $\mathrm{Zn}$ & $\mathrm{ZnSO}_{4}, 7 \mathrm{H}_{2} \mathrm{O}$ & 0 & 1.0 & 2.5 & 5.0 & 7.5 \\
\hline $\mathrm{Cu}$ & $\mathrm{CuSO}_{4}, 5 \mathrm{H}_{2} \mathrm{O}$ & 0 & 0.5 & 1.0 & 2.5 & 5.0 \\
\hline $\mathrm{Fe}$ & $\mathrm{FeSO}_{4}, 7 \mathrm{H}_{2} \mathrm{O}$ & 0 & 1.0 & 2.5 & 5.0 & 7.5 \\
\hline $\mathrm{Mn}$ & $\mathrm{MnSO}_{4}\left(\mathrm{H}_{2} \mathrm{O}\right)$ & 0 & 1.0 & 2.5 & 5.0 & 7.5 \\
\hline
\end{tabular}

Treatment details : $\mathrm{Zn}\left(\mathrm{T}_{1}\right.$, Control; $\left.T_{2}, 1.0 \mathrm{mg} \mathrm{kg}^{-1} ; \mathrm{T}_{3}, 2.5 \mathrm{mg} \mathrm{kg}^{-1} ; \mathrm{T}_{4}, 5.0 \mathrm{mg} \mathrm{kg}^{-1} ; \mathrm{T}_{5}, 7.5 \mathrm{mg} \mathrm{kg}^{-1}\right), \mathrm{Cu}\left(\mathrm{T}_{1}\right.$, Control; $\mathrm{T}_{2}, 0.5 \mathrm{mg} \mathrm{kg}^{-1} ; \mathrm{T}_{3}, 1.0 \mathrm{mg} \mathrm{kg}^{-1} ; \mathrm{T}_{4}$, $\left.2.5 \mathrm{mg} \mathrm{kg}^{-1} ; \mathrm{T}_{5}, 5.0 \mathrm{mg} \mathrm{kg}^{-1}\right)$. Fe $\left(\mathrm{T}_{1}\right.$, Control; $\left.\mathrm{T}_{2}, 1 \mathrm{mg} \mathrm{kg}^{-1} ; \mathrm{T}_{3}, 2.5 \mathrm{mg} \mathrm{kg}-1 ; \mathrm{T}_{4}, 5.0 \mathrm{mg} \mathrm{kg}^{-1} ; \mathrm{T}_{5}, 7.5 \mathrm{mg} \mathrm{kg}^{-1}\right)$ and Mn $\left(\mathrm{T}_{1}\right.$, Control; $\mathrm{T}_{2}, 1 \mathrm{mg} \mathrm{kg}^{-1} ; \mathrm{T}_{3}, 2.5$ $\left.\mathrm{mg} \mathrm{kg}^{-1} ; \mathrm{T}_{4}, 5.0 \mathrm{mg} \mathrm{kg}^{-1} ; \mathrm{T}_{5}, 7.5 \mathrm{mg} \mathrm{kg}^{-1}\right)$

Table 2 : Effect of different micronutrient treatments on number of flowers and pods per plant of senna

\begin{tabular}{|c|c|c|c|c|c|c|c|c|}
\hline \multirow[t]{2}{*}{ Treatments } & \multicolumn{4}{|c|}{ Number of flowers } & \multicolumn{4}{|c|}{ Number of pods } \\
\hline & $\mathrm{Zn}$ & $\mathrm{Cu}$ & $\mathrm{Fe}$ & $\mathrm{Mn}$ & $\mathrm{Zn}$ & $\mathrm{Cu}$ & $\mathrm{Fe}$ & $\mathrm{Mn}$ \\
\hline $\mathrm{T}_{1}$ & 43 & 41 & 42 & 40 & 34 & 32 & 35 & 32 \\
\hline $\mathrm{T}_{2}$ & 49 & 46 & 48 & 46 & 38 & 39 & 41 & 40 \\
\hline $\mathrm{T}_{3}$ & 54 & 49 & 58 & 52 & 45 & 43 & 46 & 43 \\
\hline $\mathrm{T}_{4}$ & 59 & 53 & 61 & 58 & 49 & 45 & 51 & 47 \\
\hline $\mathrm{T}_{5}$ & 56 & 49 & 59 & 54 & 48 & 45 & 50 & 44 \\
\hline CD $(5 \%)$ & 7.37 & 5.02 & 5.81 & 6.46 & 5.4 & 4.15 & 4.07 & 4.3 \\
\hline
\end{tabular}

Table 3 : Fresh and dry weight of leaves per plant of senna under different micronutrient treatments

\begin{tabular}{|c|c|c|c|c|c|c|c|c|}
\hline \multirow[t]{2}{*}{ Treatments } & \multicolumn{4}{|c|}{ Fresh leaves weight (g plant ${ }^{-1}$ ) } & \multicolumn{4}{|c|}{ Dry leaves weight (g plant ${ }^{-1}$ ) } \\
\hline & $\mathrm{Zn}$ & $\mathrm{Cu}$ & $\mathrm{Fe}$ & $\mathrm{Mn}$ & $\mathrm{Zn}$ & $\mathrm{Cu}$ & $\mathrm{Fe}$ & $\mathrm{Mn}$ \\
\hline $\mathrm{T}_{1}$ & 121.4 & 128.2 & 126.1 & 117.7 & 41.5 & 43.9 & 43.1 & 40.4 \\
\hline $\mathrm{T}_{2}$ & 154.1 & 152.9 & 165.9 & 151.7 & 52.6 & 52.4 & 56.6 & 51.8 \\
\hline $\mathrm{T}_{3}$ & 166.5 & 164.9 & 180.1 & 168.1 & 56.8 & 56.4 & 61.8 & 57.5 \\
\hline $\mathrm{T}_{4}$ & 181.6 & 177.3 & 185.7 & 159.4 & 61.3 & 60.3 & 63.3 & 54.8 \\
\hline $\mathrm{T}_{5}$ & 175.4 & 168.2 & 184.0 & 165.9 & 60.1 & 57.5 & 63.0 & 56.8 \\
\hline $\mathrm{CD}(5 \%)$ & 41.2 & 26.7 & 27.0 & 32.1 & 14.0 & 9.4 & 9.6 & 11.1 \\
\hline
\end{tabular}


Table 4 : Fresh and dry weight of pods per plant of senna under different micronutrient treatments

\begin{tabular}{|c|c|c|c|c|c|c|c|c|}
\hline \multirow[t]{2}{*}{ Treatments } & \multicolumn{4}{|c|}{ Fresh pods weight (g plant ${ }^{-1}$ ) } & \multicolumn{4}{|c|}{ Dry pods weight (g plant ${ }^{-1}$ ) } \\
\hline & $\mathrm{Zn}$ & $\mathrm{Cu}$ & $\mathrm{Fe}$ & $\mathrm{Mn}$ & $\mathrm{Zn}$ & $\mathrm{Cu}$ & $\mathrm{Fe}$ & $\mathrm{Mn}$ \\
\hline $\mathrm{T}_{1}$ & 20.35 & 20.72 & 20.12 & 20.14 & 4.11 & 4.20 & 4.13 & 4.09 \\
\hline $\mathrm{T}_{2}$ & 22.25 & 21.71 & 22.66 & 20.77 & 4.54 & 4.40 & 4.55 & 4.20 \\
\hline $\mathrm{T}_{3}$ & 23.50 & 22.53 & 24.27 & 22.30 & 4.84 & 4.64 & 4.85 & 4.45 \\
\hline $\mathrm{T}_{4}$ & 25.83 & 24.94 & 25.57 & 23.04 & 5.19 & 5.06 & 5.27 & 4.68 \\
\hline $\mathrm{T}_{5}$ & 24.33 & 23.55 & 24.97 & 22.6 & 5.00 & 4.83 & 5.23 & 4.62 \\
\hline $\operatorname{CD}(5 \%)$ & 1.90 & 1.78 & 1.65 & NS & 0.25 & 0.20 & 0.18 & 0.14 \\
\hline
\end{tabular}

Table 5 : Sennoside content (\%) in leaves and pods of senna as influenced by different micronutrient application

\begin{tabular}{lllllllll}
\hline Treatments & Leaves & \multicolumn{9}{c}{ Pods } \\
\cline { 2 - 8 } & Zn & Cu & Fe & Mn & Zn & Cu & Fe & Mn \\
\hline $\mathrm{T}_{1}$ & $2.72(1.13)$ & $2.67(1.16)$ & $2.71(1.17)$ & $2.75(1.11)$ & $3.42(0.14)$ & $3.48(0.15)$ & $3.46(0.14)$ & $3.39(0.14)$ \\
$\mathrm{T}_{2}$ & $2.30(1.20)$ & $2.11(1.09)$ & $2.26(1.28)$ & $1.80(0.91)$ & $3.17(0.14)$ & $3.14(0.14)$ & $3.31(0.15)$ & $3.02(0.13)$ \\
$\mathrm{T}_{3}$ & $2.58(1.46)$ & $2.60(1.47)$ & $2.44(1.52)$ & $1.91(1.11)$ & $3.21(0.16)$ & $3.12(0.15)$ & $3.39(0.16)$ & $3.26(0.14)$ \\
$\mathrm{T}_{4}$ & $2.76(1.74)$ & $2.34(1.41)$ & $2.67(1.75)$ & $2.23(1.22)$ & $3.63(0.19)$ & $3.11(0.16)$ & $3.62(0.19)$ & $3.13(0.15)$ \\
$\mathrm{T}_{5}$ & $2.67(1.61)$ & $2.49(1.40)$ & $2.37(1.49)$ & $2.44(1.35)$ & $3.37(0.17)$ & $3.15(0.15)$ & $3.48(0.18)$ & $3.23(0.15)$ \\
\hline $\mathrm{CD}(5 \%)$ & 0.30 & NS & 0.44 & NS & 0.27 & $\mathrm{NS}$ & 0.29 & $\mathrm{NS}$ \\
\hline
\end{tabular}

Values in parenthesis indicate sennoside yield $\left(\mathrm{g} \mathrm{plant}^{-1}\right)$

Table 6 : Micronutrient content $\left(\mathrm{mg} \mathrm{kg}^{-1}\right)$ in leaves and pods of senna under different micronutrient treatments

\begin{tabular}{lllllllll}
\hline Treatments & Leaf & \multicolumn{7}{c}{ Pod } \\
\cline { 2 - 9 } & Zn & Cu & Fe & Mn & Zn & Cu & Fe & Mn \\
\hline $\mathrm{T}_{1}$ & 27.9 & 4.71 & 222.9 & 13.45 & 19.14 & 4.29 & 173.9 & 8.91 \\
$\mathrm{~T}_{2}$ & 29.46 & 4.98 & 226.5 & 13.75 & 20.29 & 4.32 & 177.5 & 8.55 \\
$\mathrm{~T}_{3}$ & 33.31 & 5.29 & 227.7 & 12.65 & 21.76 & 4.78 & 179.3 & 8.72 \\
$\mathrm{~T}_{4}$ & 35.24 & 6.19 & 229.3 & 17.75 & 22.21 & 4.73 & 184.4 & 9.32 \\
$\mathrm{~T}_{5}$ & 30.93 & 5.54 & 228.3 & 12.25 & 21.18 & 4.54 & 177.3 & 8.78 \\
\hline $\mathrm{CD}(5 \%)$ & 6.06 & NS & 5.14 & NS & 2.89 & NS & NS & NS \\
\hline
\end{tabular}

$61.3 \mathrm{~g}$ plant ${ }^{-1}$ under $5 \mathrm{mg} \mathrm{kg}^{-1} \mathrm{Zn}$ application in soil. Fresh and dry leaf yield is the most important economic part of senna and, micronutrient application significantly enhanced the leaf yield. Similar kinds of results have been reported where dry matter and seed yield of isabgol increased with the micronutrient cations application (Basak, 2017). Increase in fresh and dry biomass yield per plant of per plant have been reported in senna due to the application of seaweed concentrate (Rani and Usha, 2013) and bio stimulants (Balakumbahan and Ragamani, 2010) which contain both macro and micronutrients. Similarly, integrated application of organic manures, biofertlizer and inorganic fertilizer improved growth and fresh and dry biomass yield of senna (Kayina et al., 2012).
Pod is the second most important economic part of senna as it contains significant amount of sennoside and the effect of various micronutrient applications on fresh and dry pod weight was recorded and presented in Table 4. The results revealed that micronutrient treatments had positively influenced the pods fresh weight per plant over control. The percentage increase over control was in the range of 12.6 to $26.9 \%$ over control. The maximum pod fresh weight was recorded ( $\left.25.83 \mathrm{~g} \mathrm{plant}^{-1}\right)$ under 5 $\mathrm{mg} \mathrm{kg}^{-1} \mathrm{Zn}$ application, followed by $25.57 \mathrm{~g}$ plant $^{-1}$ under the application of Fe @ $5 \mathrm{mg} \mathrm{kg}^{-1}$ in soil. Application of $\mathrm{Cu}$ and $\mathrm{Mn}$ increased fresh pod yield up to 20.4 and $14.4 \%$ over control. The dry pod weight followed similar trend to that of fresh weight. The application of $5 \mathrm{mg} \mathrm{kg}^{-1} \mathrm{Fe}$ and $\mathrm{Zn}$ recorded 26.3 and $27.6 \%$ 
increase in dry pod weight over control. However, the effect of $\mathrm{Cu}$ and $\mathrm{Mn}$ application was found less as compared to $\mathrm{Fe}$ and $\mathrm{Zn}$ application. Similar findings were reported by Kumar et al. (2016) who concluded that application of $\mathrm{Zn}$ and $\mathrm{Fe}$ in aromatic rice significantly increased number of tiller, dry weight and leaf area index. Similarly, application of bio stimulant which contains multi nutrient significantly increased in pod dry weight in senna (Balakumbahan and Ragamani, 2010). This increase in biomass yield might be due to stimulating effect on some physiological processes like photosynthesis and growth regulations. Iron involves in the formation of pyrrole ring plays an important structural component of chlorophyll and indispensable for chlorophyll synthesis. Similarly, Zn plays an important role in the metabolic activity in plants including chlorophyll pigment biosynthesis, important aromatic amino acids and auxin metabolisms which may stimulate plant growth activity at critical growth stage (Alloway, 2004). These findings are in agreement with the previous report where growth parameters like number of pod, fresh leaf and pod weight increased with micronutrient applications (Shilpa and Dhumal, 2012). Application of vermicompost and seaweed extract which contains both macro and micronutrient also improved yield attributes like fresh and dry weight of leaf and pod in senna (Kayina et al., 2012; Rani and Usha, 2013).

Sennoside content in both leaf and pod of senna also influenced by micronutrient application and presented in Table 5. A significant difference in sennoside content under treatments containing $\mathrm{Zn}$ and $\mathrm{Fe}$ in both leaves and pods were recorded, while treatments containing $\mathrm{Cu}$ and $\mathrm{Mn}$ were found insignificant. Overall sennoside content recorded higher in pods as compared to leaves. The highest sennoside content was recorded as 2.76 and $3.63 \%$ in leaf and pod sample under same treatment i.e., 5 $\mathrm{mg} \mathrm{Zn} \mathrm{kg}{ }^{-1}$ soil. Though micronutrient treatments did not improve sennoside content in leaves and pods, but total sennoside yield per plant was significantly improved by $\mathrm{Zn}$ and Fe application (Table 5). The highest sennoside yield was recorded $(1.94 \mathrm{~g}$ plant $^{-1}$ ) with $5 \mathrm{mg} \mathrm{kg}^{-1} \mathrm{Fe}$ application followed by $1.93 \mathrm{~g} \mathrm{plant}^{-1}$ with the application of Zn@ $@ \mathrm{mg} \mathrm{kg}^{-1}$. The increase in total leaves and pod yield per plant might be attributed to total sennoside yield per plant due the application of micronutrients, particularly $\mathrm{Zn}$ and $\mathrm{Fe}$. The application of micronutrient enhances various physiological and metabolic processes including photosynthesis (Shilpa and Dhumal, 2012) which may lead to increase in secondary metabolites in senna. The higher photosynthesis may accelerate the vegetative growth and retention of more leaves and pods in senna by accumulation of more carbohydrates (Rani and Usha, 2013) which support the present finding. These results are in agreement with the observation of Balakumbahan and Ragamani (2010) and Pratibha et al. (2010) where application of micronutrient and FYM registered significantly higher herbage yield and sennoside content under rain fed conditions.

The effect of micronutrient application on micronutrient content in leaves and pods of senna is presented in Table 6. Application of $\mathrm{Zn}$ and $\mathrm{Fe}$ in soil significantly improved their content in senna leaves, while pod micronutrient content was not influenced by micronutrient application except for $\mathrm{Zn}$. However, the application of $\mathrm{Cu}$ and $\mathrm{Mn}$ did not influence the micronutrient content in senna leaves and pods. The highest micronutrient content in senna leaves was recorded under treatment $T_{4}$ irrespective of micronutrients. Significantly higher $\mathrm{Zn}$ content in senna pods was observed under $\mathrm{T}_{4}$ treatment $\left(5 \mathrm{mg} \mathrm{kg}^{-1} \mathrm{Zn}\right.$ ) which was $16 \%$ higher than the control. Micronutrient uptake is dependent on micronutrient content and biomass yield of the crop. Overall micronutrient uptake was enhanced with high level of micronutrient application in soil under pot culture experiment (data not presented). A higher uptake of micronutrients by senna under different treatments due to additive effect of biological yield and micronutrient concentration in the tissue was observed. Foliar application of micronutrient $(\mathrm{Zn})$ in green gram under pot culture significantly increased grain Zn content (Roy et al., 2014). It was also reported that integrated application of organic manures, biofertlizer and inorganic fertilizer improved the growth and mineral uptake by senna (Kayina et al., 2012; Singaravel et al., 2016). Similarly notably increase in micronutrient content was reported in other medicinal plants i.e., Mint (Mentha arvensis) and Isabgol (Plantago ovata) due to soil application of micronutrient under pot experiment (Patra et al., 2000; Basak, 2017).

Micronutrient status of the soil after harvesting the crop was analysed and different micronutrients treatments improved soil micronutrient status. Initial soil was invariably deficient in $\mathrm{Zn}$ and $\mathrm{Cu}$, while marginally deficient in Fe and sufficient in $\mathrm{Mn}$ content (Tandon, 1999). A significant build-up of available micronutrient status in experimental soil was observed as result of the application of micronutrient treatments. The application of micronutrient salts directly contributes to the available pools which are easily accessible to plant uptake. The available micronutrient in soil is maintained by addition from external sources as well as depletion through plant uptake. Similar results were observed where significant build-up of micronutrient in soil was found after application of micronutrient salts (Basak, 2017). The integrated application of vermicompost and $\mathrm{Zn}$ enriched compost was found to improve $\mathrm{Zn}$ and other micronutrient content in soil (Chand et al., 2007). This study indicates that application Zn, Fe and Mn@ @ $5 \mathrm{mg} \mathrm{kg}^{-1}$ soil and Cu@ $2.5 \mathrm{mg} \mathrm{kg}^{-1}$ is optimum for maintaining available micronutrient status in soil after harvesting of senna.

Thus, it may be concluded that different micronutrient treatments effectively induced growth, herbage yield and sennoside content in senna. The relative performance of different micronutrients in senna demonstrated that all the micronutrients significantly improved herbage and sennoside yield over the control, while effect of $\mathrm{Zn}$ and Fe was more pronounce than the others. So, these micronutrients ( $\mathrm{Zn}$ and $\mathrm{Fe}$ ) may be recommended for commercial cultivation of senna after studying the cost benefit ratio. Moreover, this study will be very useful to farmers to promote and harvest good quality senna produce which in turn would improve the economic status of our farmers and country as well. 


\section{Acknowledgment}

The senior author is thankful to the Director, ICARDMAPR, Anand for providing necessary facilities during the period of investigation.

\section{References}

Akerele, $0 .:$ WHO guidelines for the assessment of herbal medicines. Fitotherapia, 63, 99-110 (1992).

Akhtar, N., M.S.M. Abdul, H. Akhter and N.M. Katrun: Effect of planting time and micronutrient as zinc chloride on the growth, yield and oil content of Mentha piperita. Bangladesh J. Sci. Ind. Res., 44, 125130 (2009).

Balakumbahan, R. and K. Rajamani: Effects of biostimulants on growth and yield of senna (Cassia angustifolia var KKM1). J. Hort. Sci. Ornam. Plants, 2, 16-8 (2010).

Basak, B.B.: Yield and quality of isabgol (Plantago ovata Forsk) as influenced by micronutrient application in soil. Proc. Natl. Acad. Sci. India, Sect. B Biol. Sci., 87, 671-678 (2017).

Behrouznajhad, S. and S. Zehtab-Salmasi : Effects of foliar application of $\mathrm{Fe}$ and $\mathrm{Zn}$ on seed yield and mucilage content of Psyllium (Plantago psyllium) at different stages of maturity. J Plant Physiol. Breed., 1, 21-27 (2011).

Bhatia, R.K., D.R. Lohar and D.D. Chawan: Chemical control of the yield of sennosides in Cassia acutifolia Del. Pharmaceutisch Weekblad, 2, 277-279 (1980).

Bouyoucos, G.J.: Hydrometer method improved for making particle size analysis of soils. Agron. J., 54, 464-465 (1962).

Chand, S., P. Pande, A. Prasad, M. Anwara and D.D. Patra : Influence of integrated supply of vermicompost and zinc-eniched compost with two graded levels of iron and zinc on the productivity of Geranium. Comm. Soil Sci. PlantAnal., 38, 2581-2599 (2007).

Hanway, J.J. and H. Heidel: Soil analysis methods as used in lowa State College Soil Testing Laboratory. lowa Agric., 57, 1-13 (1952).

Kayina, A., B. Das and G.S. Reddy : Effect of organic manures, biofertilizers and inorganic fertilizers on growth and yield of seena (Cassia angustifolia V). Asian J. Hort., 7, 144-147 (2012).

Keeney, D.R. and D.W. Nelson : Nitrogen mineral forms. In : Methods of Soil Analysis (Eds.: A.L. Page, R.H. Miller and D.R. Keeney) Agronomy monograph 9, Part 2, $2^{\text {nd }}$ Edn., American Society of Agronomy, Madison Wisconsin, pp. 643-698. (1982).

Kumar, A., A. Sen and R. Kumar: Micronutrient fortification in crop to enhance growth, yield and quality of aromatic rice. J. Environ. Biol., 37, 973-977 (2016).

Lindsey, W.L. and W.A. Norvell : Development of DTPA soil test for zinc, iron, manganese and copper. Soil Sci. Soc. Am. J., 42, 421-428 (1978).

Marschner, H.: Mineral nutrition of higher plant. $2^{\text {nd }}$ Edn., Academic Press. NewYork. p. 890 (1995).

Misra, A. and S. Sharma : Critical Zn concentration for essential oil yield and menthol concentration of Japanese mint. Fert. Res., 29, 261265(1991).

Naeem, M. and M.M.A. Khan: Influence of calcium on crop yield and biochemical attributes, anthraquinone and sennoside contents of cassia tora L. Roxb.-A medicinal legume. J. Herbs Spices Med. Plants, 12, 61-73 (2007).

Olsen, S.R., C.W. Cole, F.S. Watanabe and L.A. Dean: Estimation of available phosphorus in soils by extraction with sodium bicarbonate. US Department of Agriculture, Circular 939 (1954).

Patra, D.D., S. Chand, K.P. Sastry, S.P. Singh, J.R. Bahl and S.P.S. Khanuja: Agrotechnologies of senna (Cassia angustifolia). J Med. Arom. Plant Sci., 27, 101-105 (2005).

Patra, D.D., M. Anwar and S. Chand: Integrated nutrient management and waste recycling for restoring soil fertility and productivity in Japanese mint (Mentha arvensis) and mustard (Brassica juncea) sequence in Uttar Pradesh, India. Agric. Ecosyst. Environ., 80, 267-275 (2000).

Pratibha, G., G.R. Korwar and S.K. Yadav: Productivity, quality, nutrient use efficiency and economics of senna (Cassia angustifolia) as influenced by $\mathrm{FYM}$ and fertilizer nitrogen under rainfed conditions. Indian J. Agron., 55, 79-83 (2010).

Ramroudi, M., M. Galavi, B.A. Siahsar and M. Allahdoo: Effect of micronutrient and irrigation deficit on yield and yield components of isabgol (Plantago ovata Forsk) using multivariate analysis. J. Food Agric. Environ., 9, 247-251 (2011).

Rani, S.M. and R. Usha: Utilization of seaweeds in enhancing the biochemicals and productivity of Cassia angustifolia V. Indian J. Nat.Prod. Resou., 4, 184-188 (2013).

Richards, L.A.: Diagnosis and improvement of saline-alkali soils. USDA Handbook, p. 60 (1954).

Roy, P. D., R. P. Narwal, R. S. Malik, B. N. Saha and S. Kumar: Impact of zinc application methods on green gram (Vigna radiata L.) productivity and grain zinc fortification. J. Env. Bio., 35, 851-854 (2014).

Said-Al Ahl, H.A.H. and A. Mahmoud: Effect of zinc and / or iron foliar application on growth and essential oil of sweet basil (Ocimum basilicum L.) under salt stress. Ozean J. Appl. Sci., 3, 97-111 (2010).

Shilpa, M.S. and K.N. Dhumal: Influence of foliar applications of micronutrients on photosynthetic pigments and organic constituents of medicinal plant Cassia angustifolia V. Ann. Biol. Res., 3, 520-526 (2012).

Singaravel, R., D. Elayaraja and K. Viswanathan : Effect of integrated nutrient management on the growth and yield of senna in coastal sandy soil. Asian J. Soil Sci., 11, 187-190 (2016).

Srivastava, V.K., M.L. Maheshwari and S. Mandal: A rapid HPLC method for analysis of sennosides in senna. Indian J. Pharm. Sci., 45, 230231 (1983a)

Srivastava, V.K., M.L. Maheshwari and S. Mandal: Investigation of chemical assay of sennoside in senna (Cassia angustifolia V.). Int. J.Trop. Agric., 1, 231-238 (1983b).

Tandon, H.L.S.: Micronutrients in Soils, Crops and Fertilizers.: Fertilizer Development and Consultation Organization, New Delhi (1999).

Walkley, A. and I.A. Black: An examination of the Degtjareff method for determining soil organic matter and a proposed modification of the chromic acid titration method. Soil Sci., 37, 29-38 (1934). 